\title{
Consideration from Viewpoint of Output Impedance Concerning Control Method for Parallel Operation of CVCF Inverters
}

\author{
Youichi Ito Member (MYWAY Labs.) \\ Hirofumi Akagi Member (Tokyo Institute of Technorogy) \\ Zhongqing Yang Member (MYWAY Labs.)
}

Keywords: CVCF, parallel operation, output impedance, redundant operation

This paper describes the study results of the inverters running in parallel. It is a problem how to suppress the circulating current which flows among the inverters. In the consideration of the control algorithm, it is important to reveal the output impedance characteristics of the inverters. The impedance rules the circulating current.

First, Simulations demonstrate that the output impedance depends on the control scheme of the output voltage and characteristics of the circulating current differ. The output impedance was calculated in cases on a single-phase CVCF inverter. The impedance is calculated by the disturbance transfer function when the output current is assumed as the disturbance. The validity of these calculation results was confirmed by using the simulations.

Next, as examples, two control schemes and their experimental results are demonstrated. The two schemes are: "PQ droop method" based control and "common current distribution method" based control. In the former case, since the output impedance is resistive, the phase of the output voltage is adjusted by using the reactive component of the circulating current.

Figure 1 shows the latter control system. The inverters have an instantaneous output voltage feedback system with minor current loop. The load current $i_{L}$ is detected by a common current sensor and distributed to the inverters. In the case of the inverter standalone operation, the inverter output current $i_{\text {out }}$ is fed back, and in case of the inverter parallel-operation, the load current $i_{L} / n$ is fed back instead of $i_{\text {out }}$.

Table 1 indicates the calculation results of the output impedance on the Fig. 1 . When $i_{\text {out }}$ is not fed back ( $\mathrm{SW} 1=0$ ), the output impedance becomes resistance. When $i_{\text {out }}$ is fed back (SW1 = 1 ), the value of the impedance becomes $1 / 10$ of the value of the impedance when $\mathrm{SW} 1=0$. This characteristic can bring the following matters for the inverters working in parallel. Because the load current is fed back (SW1 = 0), in the inverters running in parallel, the output impedance to the load is same as that of the stand-alone inverter. Consequently, the inverters can offer the same output-voltage performance as that of the stand-alone inverter. When the inverter output current is not fed back (SW1 $=1)$, the output impedance between inverters is ten times the output impedance to the load, and then the circulating current hardly flows between inverters.

Figure 2 indicates the output voltage waveforms when two $100 \mathrm{kVA}$ inverters are connected in parallel. $1.4 \%$ of the total harmonic distortion of the waveforms is obtained at $100 \%$ capacitive rectifier load. In this case, each inverter shares the load within 5\% of error.

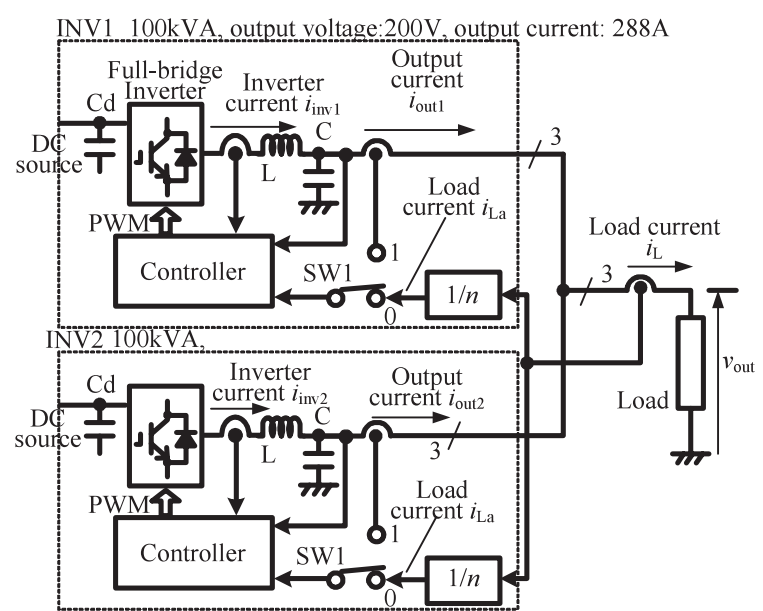

Fig. 1. Parallel operation controller for inverter with instantaneous output voltage control

Table 1. $Z_{\text {out }}$ calculation results with Fig. 1 controller

\begin{tabular}{|l|l|l|l|l|}
\hline Operation & \multicolumn{1}{|c|}{ Conditions } & \multicolumn{3}{|c|}{ Output impedance } \\
\cline { 3 - 5 } State & & Item & Gain & Phase \\
\hline \multirow{2}{*}{$\begin{array}{l}\text { Stand } \\
\text { alone }\end{array}$} & With feedback of $i_{\text {out }}$ & $Z_{\text {out }}$ & $\begin{array}{l}0.025 \Omega \\
(6.3 \%)\end{array}$ & $90^{\circ}$ \\
\hline Parallel & Without feedback of $i_{\text {out }}$ & $Z_{\text {outs }}$ & $\begin{array}{l}0.25 \Omega \\
(63 \%)\end{array}$ & $180^{\circ}$ \\
& $($ SWl=0) & & $(63 \%)$ & \\
\cline { 2 - 5 } & With feedback of $i_{L a}$ & $Z_{\text {outa }}$ & $\begin{array}{l}0.025 \Omega \\
(6.3 \%)\end{array}$ & $90^{\circ}$ \\
& $(\mathrm{swl}=0)$ & & & \\
\hline
\end{tabular}

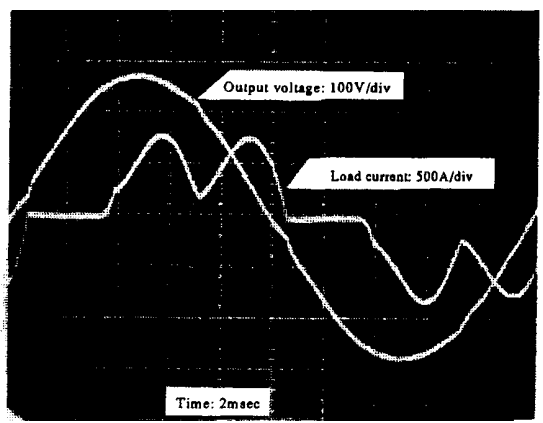

Fig. 2. Output Voltage and Output Current Waveforms at $200 \mathrm{kVA}$ rectifier load 


\title{
出力インピーダンスに着目したCVCFインバータ並列制御の考察
}

\author{
正 員 伊東 洋一* 正 員 赤木 泰文** \\ 正員楊仲慶*
}

\section{Consideration from Viewpoint of Output Impedance Concerning Control Method for Parallel Operation of CVCF Inverters}

\author{
Youichi Ito*, Member, Hirofumi Akagi**, Member, Zhongqing Yang*, Member
}

\begin{abstract}
This paper describes the study results of the inverters running in parallel. In the consideration of the operation algorithm, it is important to reveal output impedance characteristics of the inverters. First, simulation results demonstrate that the output impedance depends on the control scheme of the output voltage and characteristics of the circulating current that flows through the inverter differs. Next, as examples, two control schemes and their experimental results are demonstrated. The two schemes are: "PQ droop method" based control and "common current distribution method" based control. In the both case, since the output impedance is resistive, the phase of the output voltage is adjusted by using the reactive component of the circulating current. The amplitude of the output voltage is not manipulated. In the latter control system, quantity of the output-current feedback changes with the output impedance. This characteristic clarifies that the output impedance among the inverters becomes higher and the output impedance of the loads gets smaller. Moreover, suppression of the circulating current and excellent output voltage characteristics can be maintained.
\end{abstract}

キーワード : CVCF, 並列運転, 出力インピーダンス, 圥長運転

Keywords: CVCF, parallel operation, output impedance, redundant operation

\section{1.はじめに}

近年，IT 社会のますますの高度化に伴い，それらに電力 を供給する電源システムに対して, 高品質, 高信頼性, シス テムの拡張性, 省エネルギーが要求される。高品質化を実 現するためにバッテリと CVCF インバータを組み合わせた 無停電電源システムが使われる。さらに高信頼性を得るた めには，インバー夕等の変換器を並列圥長運転させる。ま た容量の拡張性や MTTR の短縮，メンテナンスの容易性か ら，N+1 台のシステム構成とすることが一般的である(1)。 さらに省エネルギー化を推進するために新電力供給システ ムとして分散型電源と組み合わせて「FRIENDS」，「DCマ イクログリッド」「直流多端子網」等が提唱され実用化研究 が行われている。これらのシステムにおいても, CVCF イ ンバータの役割は重要であり, $\mathrm{N}+1$ 台のインバー夕並列

\footnotetext{
*マイウエイ技研

干 222-0033 横浜市港北区新横浜 1-14-15

Myway Labs. Co. Ltd.

1-14-15, Shin-Yokohama, Kouhoku-ku, Yokohama 222-0033

** 東京工業大学 大学院理工学研究科電気電子工学専攻

干 152-8552 東京都目黒区大岡山 2-12-1

Tokyo Institute of Technology

2-12-1, O-okayama, Meguro-ku, Tokyo 152-8552
}

運転の技術が必要となる (2)。

現在までの主な CVCF インバー夕の並列運転方式は文 献(3)～(6) で報告されている。これらを大別すると，1) 出 力の無効電力, 有効電力により電圧, 周波数に垂下特性を 持たせて制御するもの (以下 PQ 垂下方式)，2) 共通負荷 電流を各インバータに分配して循環電流を抑制するように 電圧, 周波数を制御するもの (以下, 共通電流分配方式), 3) インバータをマスターとスレーブにわけるものがある。 1) は並列制御のための信号を各インバータに分配する必要 がないのでその分だけ信頼性を高くできる。しかし, 出力 電圧, 周波数に垂下特性をもっており, 出力特性は悪化す る。また故障検出も難しい。2) 3) は, 共通の信号線を各イ ンバータが必要とするため, その部分により信頼性は低下 するが, 瞬時の制御が可能であり, 良好な出力電圧特性が得 られる。さらに3)においては，マスターが故障したとき， スレーブがマスターに切り替わる部分で信頼性が決まる。

いずれの方式にせよインバータの並列制御を考える場合, インバータ間において出力電圧の振幅差, 位相差により発 生する循環電流を抑制制御することが課題である。この循 環電流の特性は出力インピーダンス $Z_{\text {out }}$ により決まる。現 在までの発表文献では，この $Z_{\mathrm{out}}$ について議論されていな いようである。単にリアクトルを仮定し，その值もあいま 
いなものが多い。 $Z_{\text {out }}$ が大きければ，並列時の循環電流制 御に高速性は要求されないが, 負荷に対する出力電圧特性 が悪化する。したがって， $Z_{\text {out }}$ を明確に定義し，制御系を 構築しなければ応用範囲が限定される。

本論文では，はじめにインバー夕の主回路定数，制御方 式により $Z_{\mathrm{out}}$ と循環電流特性が決まることを示し，シミュ レーションにより確認する。 $L-C$ フィルタを備える $1 \mathrm{kVA}$ 単相インバータにおいて，負荷電流は外乱成分としてモデ ル化する。このモデルでは, $Z_{\mathrm{out}}$ は外乱伝達関数となる。次 に，事例として PQ 垂下方式と共通電流分配方式について $Z_{\text {out }}$ を考察し, 並列制御系を構築する。PQ垂下方式ではイ ンバータの出力電圧の平均值を制御する系についての結果 について示す。共通電流分配方式の結果では，文献(7)に 示した方式の電圧制御系を基に並列制御系を構成する。そ して，実験結果によりその妥当性を示す。

\section{2. 電圧制御系とインバータ間循環電流の特性}

本章では, インバータの制御方式により $Z_{\mathrm{out}}$ と循環電流特 性が決まることを示し, シミュレーションにより確認する。

〈2・1〉主回路モデルと出カインピーダンス＼cjkstart図 1(a) に本章で検討するインバータの主回路と制御回路を示す。

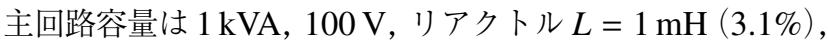
コンデンサ $C=10 \mu \mathrm{F}$ （カットオフ周波数 $1.6 \mathrm{kHz）とし}$ た。出力電圧制御系と $Z_{\text {out }}$ の関係について次の 3 通りを検 討する。

Case 1：電圧制御なし $(\mathrm{SW}=0)$, デッドタイム $T_{d}=0 \mu \mathrm{s}$

Case 2 : 電圧制御なし $(\mathrm{SW}=0)$, デッドタイム $T_{d}=3 \mu \mathrm{s}$

Case 3：電圧制御あり $(\mathrm{SW}=1)$, デッドタイム $T_{\mathrm{d}}=3 \mu \mathrm{s}$ 図 1(a) の主回路および制御回路は同図 (b) のようなブ ロック線図で示すことができる(7)。ここで，抵抗 $r_{d}$ はデッ ドタイムによる電圧降下分を模擬したものである。ブロッ ク線図において, 出力電圧 $V_{\text {out }}$ は

$$
V_{\text {out }}=G_{\mathrm{r}}(s) V_{\text {ref }}+G_{\mathrm{d}}(s) I_{\text {out }}
$$

ただし, $G_{\mathrm{r}}(s)$ : 指令值伝達関数, $G_{\mathrm{d}}(s)$ : 外乱伝達関数で示さ れる。右辺, 第 2 項が, 出力電流 $I_{\text {out }}$ に対する出力電圧 $V_{\text {out }}$ の 変動分 $\Delta V_{\text {out }}$ なる。出力インピーダンスは $Z_{\text {out }}=\Delta V_{\text {out }} / I_{\text {out }}$ の関係がある。よって，基本波周波数を $\omega(\mathrm{rad} / \mathrm{sec})$ とすれ ば, $Z_{\mathrm{out}}=\left.G_{\mathrm{d}}(s)\right|_{s=j \omega}$ であり, $Z_{\mathrm{out}}$ の特性は外乱伝達関数 $G_{\mathrm{d}}(s)$ により決まる。主回路 L-C フィルタの值, 制御系の 構成，ゲインの設定により $G_{\mathrm{d}}(s)$ の特性は変化する。

各 Case についての $G_{\mathrm{d}}(s)$ はブロック図の変形により導 出（付録参照）でき, $Z_{\text {out }}=\left.G_{\mathrm{d}}(s)\right|_{s=j \omega}$ 下記の通りとなる。

Case1 $: Z_{\text {out }}=j \omega L \quad$ (誘導性 $)$

Case $2: Z_{\text {out }}=r_{d}+j \omega L, \quad r_{d} \gg \omega L \quad$ （抵抗性）

Case3 $: Z_{\text {out }}=\left\{L \omega^{2}+j\left(r_{d}+E_{d}\right) \omega\right\} /\left(K_{i} E_{d}\right) \quad$ (誘導性 $)$

$$
L \omega^{2} \ll\left(r_{d}+E_{d}\right) \omega
$$
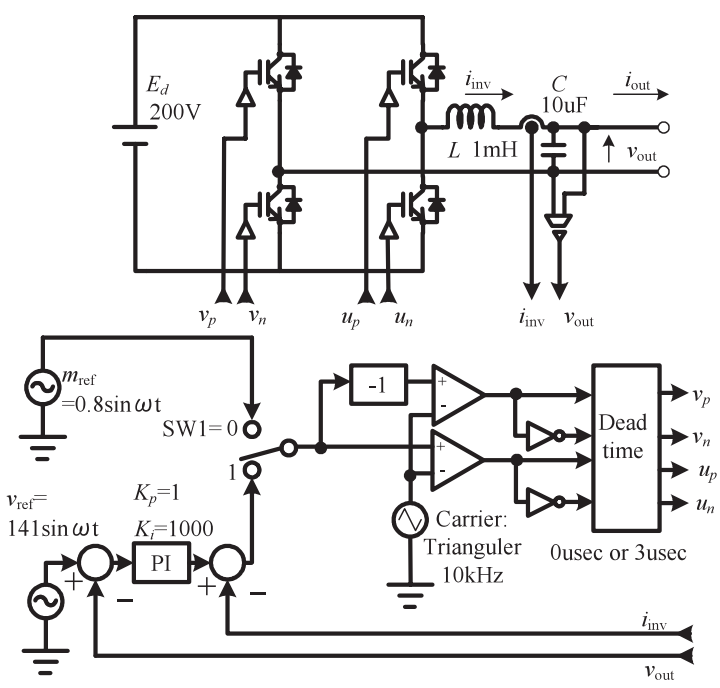

(a) Main and control circuit

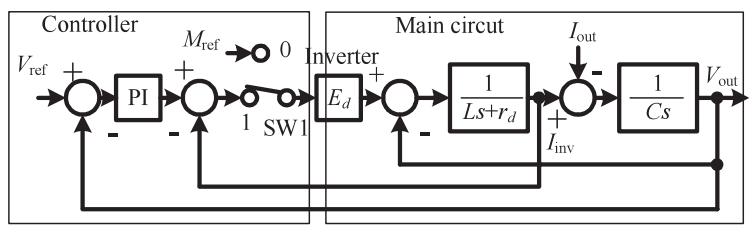

(b) Control block diagram for Fig. (a)

図 1 出力インピーダンス検討回路

Fig. 1. Output impedance consideration circuit.

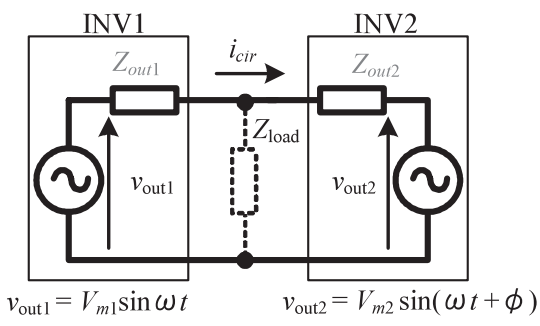

図 2 インバー夕並列時の等価回路

Fig. 2. Equivalent circuit of inverter in parallel.

〈2・2〉 出カインピーダンスと循環電流の関係図 2 に 2 台のインバータ INV1, INV2 が並列しているときの 単相等価回路を示す。インバータは電圧源に直列に $Z_{\mathrm{out} 1}$, $Z_{\text {out2 }}$ を接続した回路で示される。インバー夕間の電圧差, 位相差により流れる電流を循環電流 $i_{\mathrm{cir}}$ とする。負荷イン ピーダンス $Z_{\mathrm{load}}$ は $i_{\mathrm{cir}}$ の計算に関係しないので簡略化のた め省略する。この回路において, $i_{\text {cir }}$ は, フェザーベクトル を用いて次ように計算される。

$$
\begin{gathered}
\dot{I}_{\text {cir }}=\left(\dot{V}_{\text {out } 1}-\dot{V}_{\text {out } 2}\right) /\left(Z_{\text {out } 1}+Z_{\text {out } 2}\right) \cdots \cdots \cdots \cdots(5) \\
\text { ただし }, \dot{I}_{\text {cir }}: i_{\text {cir }} \text { のフェザーベクトル } \\
\dot{V}_{\text {out } 1}=V_{\mathrm{m} 1} \angle 0: \text { INV1 の出力電圧ベクトル } \\
\dot{V}_{\text {out } 2}=V_{\mathrm{m} 2} \angle \phi: \text { INV2 の出力電圧ベクトル }
\end{gathered}
$$

インバータ電圧の振幅に差がある場合（位相差 $\phi=0^{\circ}$ ) は，次のようになる。

$$
\dot{I}_{\text {cir }}=\left(V_{\mathrm{m} 1}-V_{\mathrm{m} 2}\right) /\left(2 Z_{\text {out }}\right)
$$




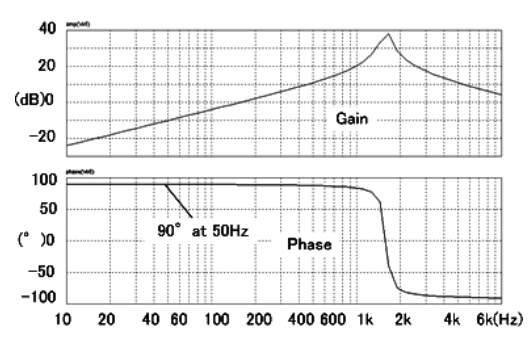

(a) Frequency characteristics of $\mathrm{G}_{\mathrm{d}}(\mathrm{s})=$ Vout/Iout

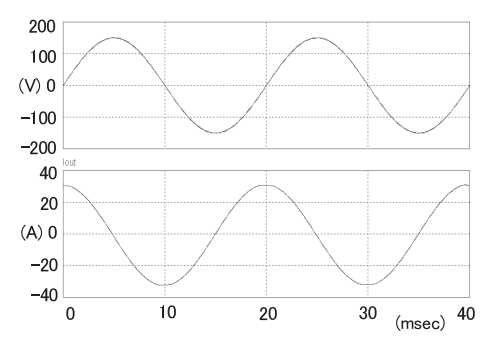

(b) Circulating current when voltage difference is $20 \mathrm{~V}$

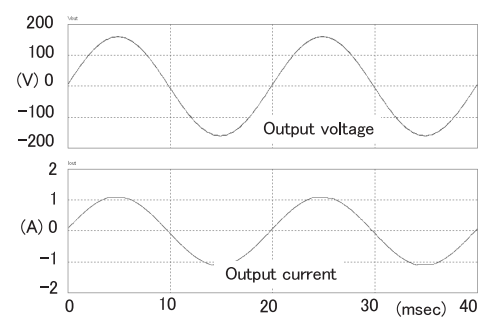

(c) Circulating current when $\phi$ is $5^{\circ}$

No feedback control, Dead time $=0 \mu \mathrm{sec}$

図 3 シミュレーション結果：Case1

Fig. 3. Simulation result: case1.

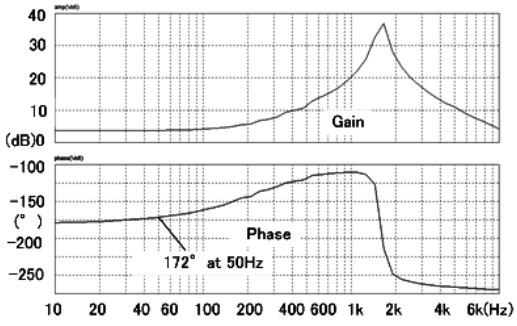

(a) Frequency characteristics of $G_{d}(s)=$ Vout/Iout

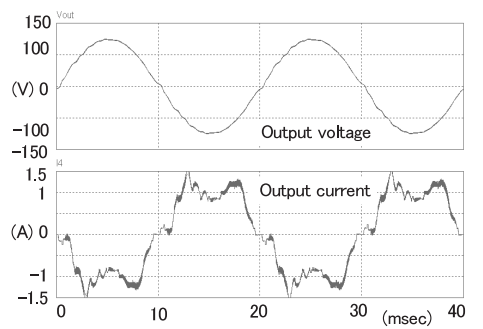

(b) Circulating current when voltage difference is $20 \mathrm{~V}$

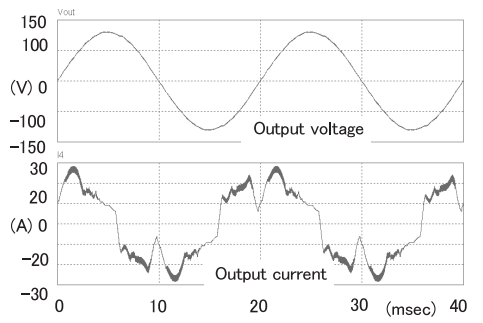

(c) Circulating current when $\phi$ is $5^{\circ}$

No feedback control, Dead time $=3 \mu \mathrm{sec}$

図 4 シミュレーション結果：Case2

Fig. 4. Simulation result: case2.

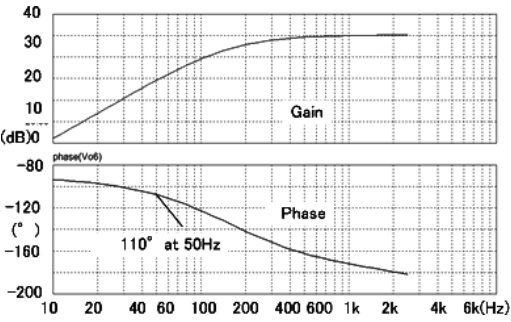

(a) Frequency characteristics of $\mathrm{G}_{\mathrm{d}}(\mathrm{s})=$ Vout/Iout

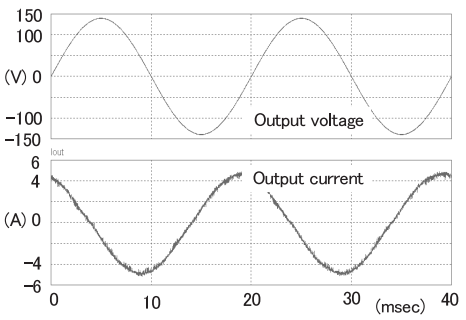

(b) Circulating current when voltage difference is $3 \mathrm{~V}$

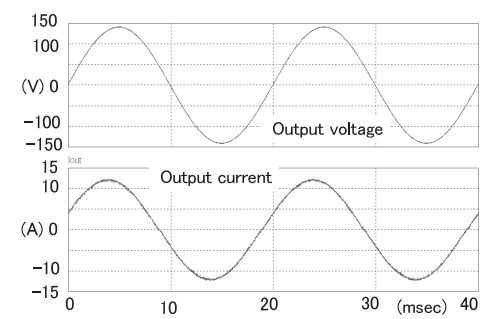

(c) Circulating current when $\phi$ is $3^{\circ}$

Feedback control, Dead time $=3 \mu \mathrm{sec}$

図 5 シミュレーション結果：Case3

Fig. 5. Simulation result: Case3.

$$
\text { ただし } Z_{\text {out }}=Z_{\text {out1 }}=Z_{\text {out } 2} \text { とする。 }
$$

一方，インバータの電圧振幅が同じで位相が異なる場合 は，以下のようになる。

$$
\dot{I}_{\text {cir }}=j V_{\mathrm{m}} \sin \phi /\left(2 Z_{\text {out }}\right)
$$

$\langle 2 \cdot 3\rangle$ 出力電圧制御系と循環電流特性 (6), (7) 式と (2) (4) 式の $Z_{\text {out }}$ から，表 1 に制御系に対する循環電流の 特性を示す。この結果をシミュレーションにより確認する。 シミュレーション・ツールにはPSIM (Power Sim 社) を用 いた。外乱伝達特性 ( $I_{\mathrm{out}}$ に対する $V_{\mathrm{out}}$ の周波数特性) は, PSIM の「AC SWEEP 機能 」を利用する。さらに, 図 1(a) の回路を 2 並列にして, 指令值 $v_{\text {ref }}$ または $m_{\text {ref }}$ に電圧差ま たは位相差が存在する場合の波形を計算する (無負荷状態)。 デッドタイムにより発生する抵抗分 $r_{d}$ は事例 1 の実験より $1.5 \Omega$ とした（次章で測定および計算值を示す）。

†本機能の概要を以下に説明する。時間領域において, 対象回路の 指定した節または枝に正弦波信号を入力し，指定した節または枝の出 力信号波形を観測する。定常状態になったことを判断し, 入出力信号 の振幅差, 位相差を計測する。入力信号の周波数を決められた範囲, ステップで変化させて, 繰り返し入出力信号の振幅差, 位相差を計測 する。そして，周波数に対する振幅差，位相差の曲線を描き，周波数 特性を求める。MATLAB/Simulink（MathWorks 社）にあるような，方 程式を線形化し周波数領域で周波数特性を求めるものではない。

\section{表 1 出力インピーダンスと循環電流の性質}

Table 1. Characteristics of output impedance and circulating current.

\begin{tabular}{|l|l|c|c|}
\hline & \multirow{2}{*}{$\begin{array}{l}\text { Zout } \\
\end{array}$} & 特性 & \multicolumn{2}{|c|}{ 循環電流の性質 } \\
\cline { 3 - 4 } & 出力電圧の振幅差 & 出力電圧の位相差 \\
\hline Case 1 & 誘導性 & 無効電流 & 有効電流 \\
\hline Case 2 & 抵抗性 & 有効電流 & 無効電流 \\
\hline Case3 & 誘導性 & 無効電流 & 有効電流 \\
\hline
\end{tabular}

図 3〜図 5 に各 Case におけるシミュレーション結果を 示す。図中 (a) に周波数特性, (b), (c) に並列運転時の循環 電流波形を示す。

図 3(a) Case1 において, $50 \mathrm{~Hz}$ の点の位相は入力に対し て $90^{\circ}$ である。同図 (b), (c)より, 並列運転時, 電圧差があ る場合は無効電流, 位相差がある場合は有効電流が流れて いる。これらより， $Z_{\text {out }}$ は誘導性であることが確認できる。

図 4(a) Case2 において, デッドタイム $T_{d}$ の影響で, 図 3(a) に対して周波数特性が変化し, $50 \mathrm{~Hz}$ の点において, 位相差 は約 $180^{\circ}$ である。 $T_{d}$ は $Z_{\text {out }}$ に大きく影響する。同図 (b), (c)より循環電流は $T_{d n}$ の影響により，ひずんでいるが電圧 差がある場合は有効電流, 位相差がある場合は無効電流と なっていることがわかる。以上， $Z_{\text {out }}$ が抵抗性であること 
が確認できる。

図 5(a) Case3 において，瞬時電圧フィードバック制御を 行った場合，周波数特性における $50 \mathrm{~Hz}$ 点の位相は $110^{\circ}$ で ある。同図 (b), (c)より，循環電流は，電圧差がある場合 は無効電流，位相差がある場合，有効電流がとなっている。 よって $Z_{\text {out }}$ は誘導性であることが確認できる。

以上，インバータ制御系の外乱伝達関数から $Z_{\mathrm{out}}$ の特性 を求め, シミュレーションによりその妥当性を確認した。 デッドタイムや制御系の構成で $Z_{\text {out }}$ の特性が変化する。し たがって，単機のインバータ電圧制御系の設計方針と特性 を明確にたうえで，PQ垂下方式や共通電流分配方式等，並 列制御方式を開発しなければならない。

3. 事例 1 : 出力電圧平均值フィードバック系を備え るインバータの並列制御

〈3・1〉 制御系と出カインピーダンスの考察 出力電圧 の平均值に指令值を追従するような出力電圧フィードバッ ク系を備えるインバータの並列運転を，PQ垂下方式を用い て実現する。図 6 に主回路構成と制御回路構成を示す。同 図 (a)において，L-Cの值は図 1 と同じである。各インバー 夕間の信号の授受はなく, 各インバータは自身のインバータ 電流と出力電圧のみを検出する。同図 (b) において, PWM キャリアは $20 \mathrm{kHz}$ で, 操作量 $m_{r e f}$ との比較でインバータ 駆動の PWM を発生させている。 $m_{r e f}$ は, 正弦波発振器か らの $\sin \omega \mathrm{t}$ に平均值電圧制御系から出力される $V_{m \_r e f}$ を乗 算した信号である。出力電圧の平均值 $V_{\text {out_ave }}$ は, 検出した 出力電圧を絶対值変換し，カットオフ周波数 $1.6 \mathrm{~Hz}$ の低域 通過フィル夕 (LPF) で平滑化したものである。平均值電 圧制御系において，PI 補償器は， $V_{\text {out_ave }}$ と指令值 $V_{\text {out }}^{*}$ の 誤差が零となるような $V_{\mathrm{m} \_ \text {ref }}$ を出力する。

このような平均值電圧制御系を備えるインバータでは $Z_{\mathrm{out}}$ は上記 Case2 と同じ抵抗性となる。理由として，平均值制 御系の固有周波数は $1 \mathrm{~Hz}$ 以下であり， $Z_{\mathrm{out}}$ は基本波周波数 $\omega=2 \pi 50 \mathrm{~Hz}$ の特性である。両者の周波数は 10 倍以上離れ ているため, 平均值制御系は $Z_{\mathrm{out}}$ に影響を与えないからで ある。実験により，このインバータの出力インピーダンス 特性を確認した。二台のインバータにおいて, 故意に $-8.3^{\circ}$ の位相差を与える。そのときの出力電圧と循環電流の観測 波形を図 7 に示す。上記で述べたとおり，位相差で無効電 流が流れることが確認できた。さらに，デッドタイムによ り発生する等価抵抗 $r_{d}$ を次のように測定した。平均值制御 がない状態で運転し, 無負荷時と定格抵抗負荷時 $(10 \mathrm{~A})$ の 出力電圧を測定した。その結果から出力電圧変動分 $\Delta V_{\text {out }}$ は $18 \mathrm{~V}$ であった。これより， $Z_{\mathrm{out}}=18 \mathrm{~V} / 10 \mathrm{~A}=1.8 \Omega$ と なる。さらに，(3)式よりリアクトル分を除き， $r_{d}=1.5 \Omega$ となった。

$\langle\mathbf{3} \cdot 2\rangle$ 並列制御系の構成 以上の $\mathrm{Z}_{\mathrm{out}}$ 特性から並列 運転のため $\mathrm{P}-\mathrm{Q}$ 方式に基づく制御系を構成すると，図 6(b) に示す循環電流制御器（破線で囲まれる部分）となる。イ ンバータ間に周波数や位相差があると無効電流が流れるの

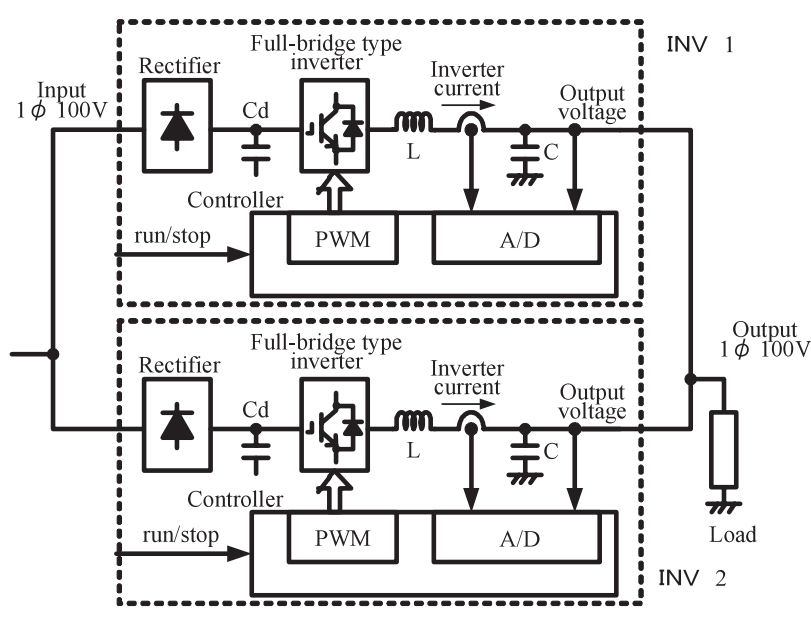

(a) Main circuit configuration

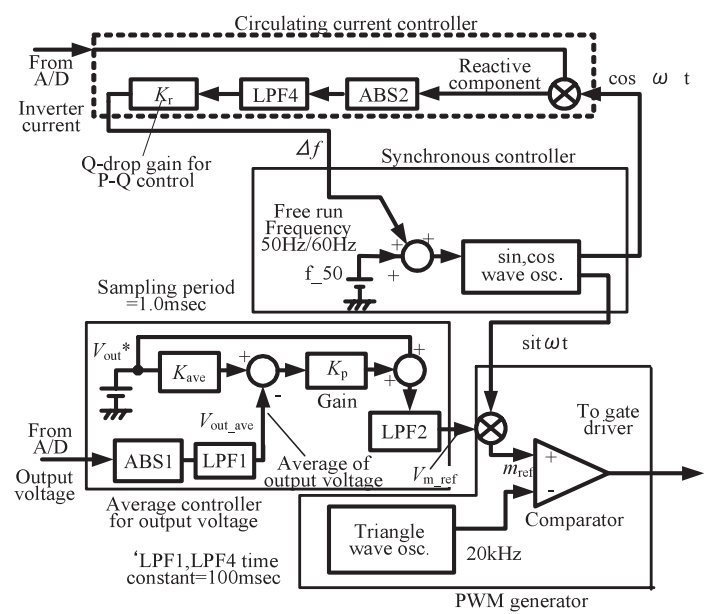

(b) Inverter Controller

図 6 出力電圧平均值制御系を持つインバータ

Fig. 6. Inverter with average output voltage controller.

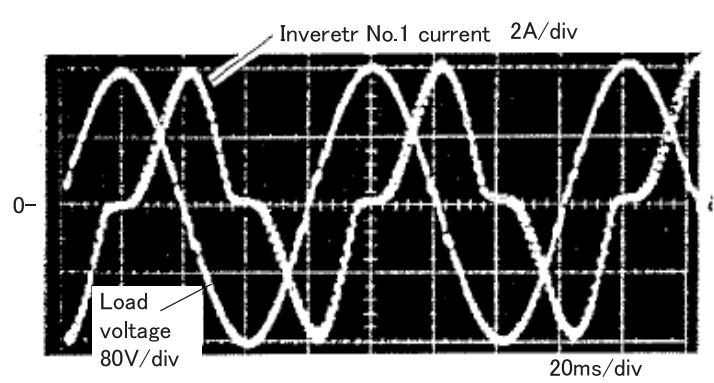

図 7 No.1 インバータ出力電流 (位相差 $-8.3^{\circ}$ )

Fig. 7. Inverter 1 output current at phase difference of 8.3 degree.

で，インバータ電流の無効分により出力周波数を垂下させ る。無効分の検出は, 次のようにした。内部にある出力電 圧指令と $90^{\circ}$ 位相が異なる $\cos \omega \mathrm{t}$ 信号と乗算する。この信 号の絶対值をとり，フィルタを通すことでインバータ電流 の無効分を求めている。そして, その無効分にゲイン $K_{r}$ を 乗算して周波数垂下量 $\Delta f$ としている。定格無効電力を出 力時に出力周波数が $0.1 \%(50 \mathrm{~Hz}$ 時, $0.05 \mathrm{~Hz})$ 变化するよ 
うにゲイン $K_{\mathrm{r}}$ を決めた。

さらに, $\mathrm{P}-\mathrm{Q}$ 方式に従えば, インバー夕電流の有効分によ り出力電圧を垂下させなければならないが, 次のことから 図 6(b) の循環電流制御器は, この機能を有していない。各 インバータに扔いて, 単機での定格運転時の出力電圧值が $100 \mathrm{~V} \pm 1 \mathrm{~V}$ 以内になるように出力電圧センサのレンジ, オフ セットを調整する。デジタル制御をしているため特性の経年 変化や温度等による变化が少なく, この調整は一度だけ行え ばよい。この調整により出力電圧差は, 最大 $2 \mathrm{~V}$ となる。循 環電流の最大は $Z_{\text {out }}=1.8 \Omega$ より $2 \mathrm{~V} /(1.8 \Omega \times 2$ 台 $)=0.55 \mathrm{~A}$ である。この值は定格電流 $10 \mathrm{~A}(100 \mathrm{~V}, 1 \mathrm{kVA})$ の $5.5 \%$ で あり, 実用上問題ない範囲である。したがって, 循環電流 制御器には特に出力電圧の垂下機能は備えていない。

$\langle\mathbf{3} \cdot 3\rangle$ 実験結果 図 8 に図 6(a) の接続で2 台のイン バー夕を並列運転させたときの実験結果を示す。同図 (a) は, インバータ INV2, 1 台で $1 \mathrm{~kW}$ 負荷に電力を供給中, INV1 を並列投入したときの波形である。同図 (b) は, INV1， INV2 で $1 \mathrm{~kW}$ 負荷に電力を供給中, INV1 を解列した時の 波形を示す。INV1 の投入解列時, INV2 に過大な電流が流 れていない。つまり，循環電流がながれないことがわかる。 さらに，並列運転中の負荷電流分担の差は 5\%以内で，ほ ほ均等に分担していた。すなわち，定常時に扔いて循環電 流は 5\%以内である。以上，上記で構成した循環電流制御 器の有効性が確認できた。

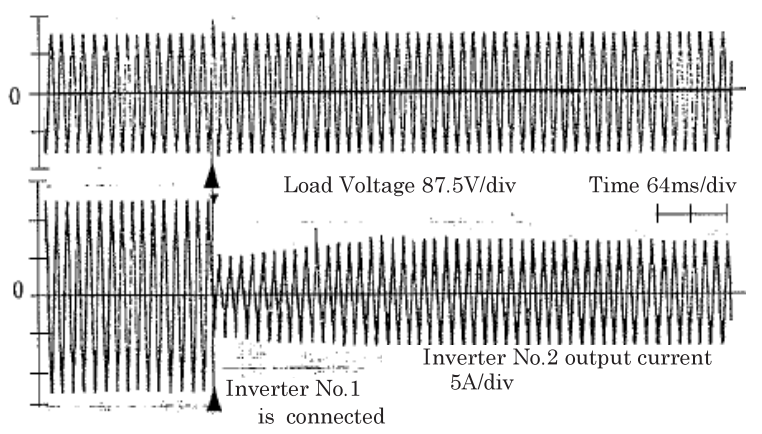

(a) No.1 Inverter connected to No.2

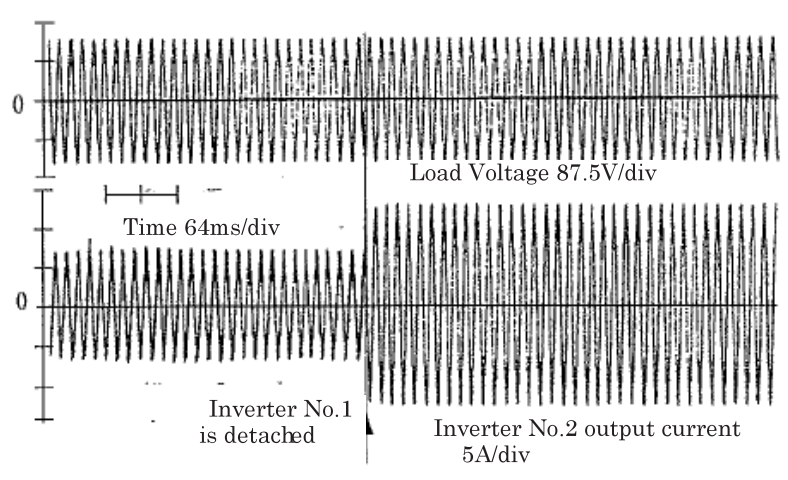

(b) No.1 Inverter disconnected form No.2

図 8 出力電圧平均值制御系をもつインバータの 並列運転実験結果

Fig. 8. Experimental results for parallel operation of inverters with average output voltage controller.
4. 事例 2 : 瞬時出力電圧フィードバック系を備える インバータの並列制御

〈4・1〉 制御系と出カインピーダンスの考察 図 9(a) に瞬時出力電圧フィードバック系を備える三相インバー夕 の並列システムを示す。装置容量は単機 $100 \mathrm{kVA}$ （線間電 圧 $200 \mathrm{~V})$ である。それぞれのインバー夕の制御器は, 出 力電圧 $v_{\text {out }}$, インバー夕電流 $i_{\text {inv }}$ のほかに, インバー夕出力 電流 $i_{\text {out }}$ または平均負荷電流 $i_{\mathrm{La}}$ をフィードバックする。並 列制御法は，共通電流分配方式を用いる。この共通負荷電 流 $i_{\mathrm{L}}$ のセンサは並列運転のために増える要素である。1 台 単独運転の場合, SW1 は 1 , 並列運転の場合は 0 になる。 $\mathrm{SW} 1=1$ の場合, 制御器はインバー夕の出力電流 $i_{\text {out }}$ を フィードバックするが, SW1 = 0 の場合, 共通負荷電流を 並列台数 $n$ で除算した平均負荷電流 $i_{\mathrm{La}}=i_{\mathrm{L}} / n$ をフィード バックする。

図 9(b) は一相分の出力電圧制御系のブロック図を示す。 単機運転時の出力電圧制御器には文献(7) を採用している。 メジャ・ループとして出力電圧フィードバック系があり, マ

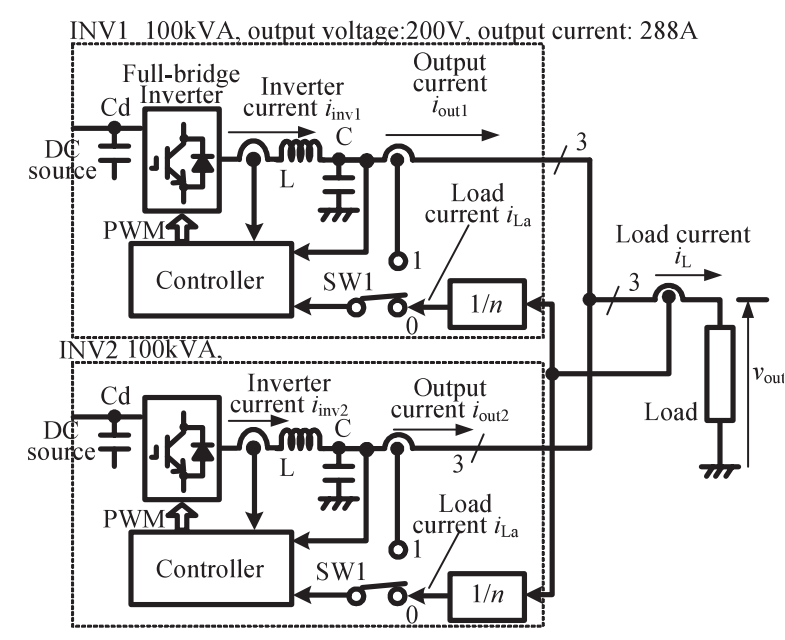

(a) System configuration

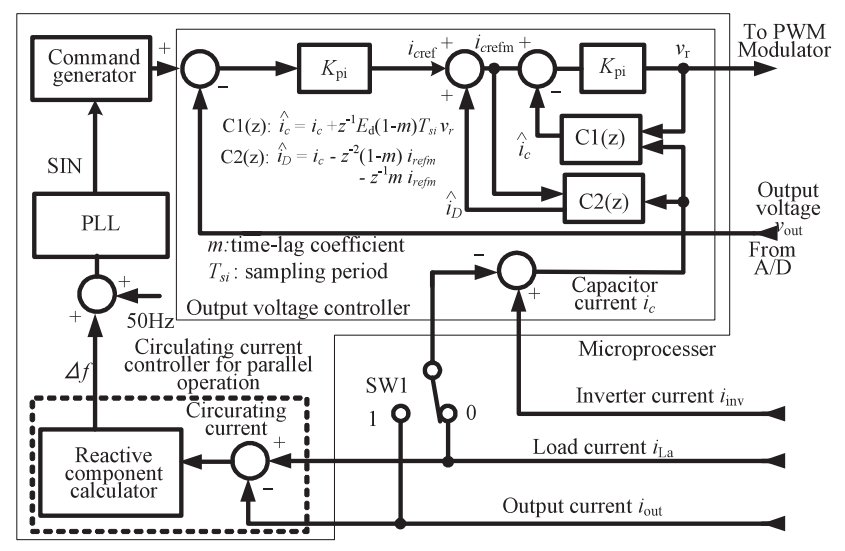

(b) Inverter controller block diagram

困 9 瞬時出力電圧制御系を持つインバー夕並列制御

Fig. 9. Parallel operation controller for inverter with instantaneous output voltage control. 


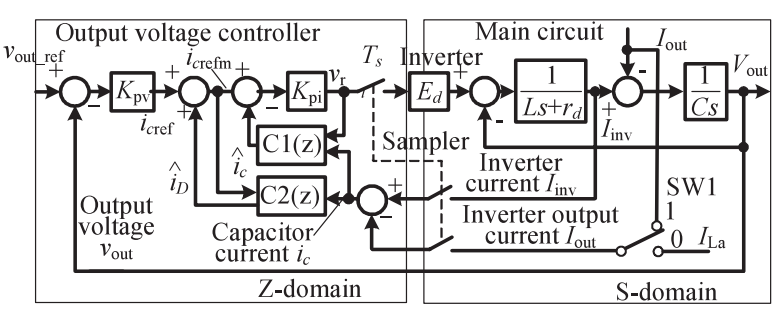

図 10 図 9 の主回路を含む制御系ブロック図

Fig. 10. Control block diagram of Fig. 9 containing main circuit.

表 2 制御器図 9(b) を用いた場合の $Z_{\text {out }}$ 計算結果

Table 2. $Z_{\text {out }}$ calculation results with Fig. 9(b) controller.

\begin{tabular}{|c|c|c|c|c|}
\hline \multirow{2}{*}{$\begin{array}{l}\text { 運転 } \\
\text { 状態 }\end{array}$} & \multirow[t]{2}{*}{ 条件 } & \multicolumn{3}{|c|}{ 出カインピーダンス } \\
\hline & & 記号 & ゲイン & 位相 \\
\hline 単機 & $\begin{array}{l}\text { インバータ出力電流 } i_{o u} \\
\text { フィードバック }\end{array}$ & $Z_{\text {out }}$ & $\begin{array}{l}0.025 \Omega \\
(6.3 \%)\end{array}$ & $90^{\circ}$ \\
\hline \multirow[t]{2}{*}{ 並列 } & $\begin{array}{l}\text { インバータ出力電流 } \\
\text { フィードバックなし }\end{array}$ & $Z_{\text {outs }}$ & $\begin{array}{l}0.25 \Omega \\
(63 \%)\end{array}$ & $180^{\circ}$ \\
\hline & $\begin{array}{l}\text { 負荷平均電流 } i_{L a} \\
\text { フィードバックり }\end{array}$ & $Z_{\text {outa }}$ & $\begin{array}{l}0.025 \Omega \\
(6.3 \%)\end{array}$ & $90^{\circ}$ \\
\hline
\end{tabular}

()内の值は\%インピーダンスを示す。

イナ・ループとして $L-C$ フィルタのコンデンサ電流 $\left(i_{\mathrm{inv}}{ }^{-}\right.$ $\left.i_{\text {out }}\right)$ フィードバック系がある。並列運転のために追加した 機能は循環電流制御器と電流検出切り替えのスイッチ SW1 である。循環電流制御器の構成（図中, 破線で囲まれる部 分）については, 次節以降で, 出力インピーダンス特性を 明らかにした後，説明をする。

第2 章において電圧フィードバック制御がある場合, Case3 として $Z_{\text {out }}$ の特性を示したが, 電圧制御器の構成が異なる ため，新たに，外乱伝達関数を求め $Z_{\text {out }}$ の性質を調べる必 要がある。図 1(b)において制御器を図 9(b) に示す電圧制 御器に置き換えたブロック線図を図 10 に示す。制御器の 構造が PI 補償器に比べ複雑であることと, 制御器は離散 化領域 ( $\mathrm{z}$ 領域), 主回路は連続領域 ( $\mathrm{s}$ 領域) であること から，ブロック図の変形により外乱伝達関数を求めること は難しい。そこで，制御解析ソフトウェア Matlab/simulink (Mathwork 社) を用いて $50 \mathrm{~Hz}$ 時の外乱伝達特性，すなわ ち出力インピーダンスを計算した。その結果を表 2 に示す。 図 9(b) に示す電圧制御器では， $i_{\text {out }}$ のフィードバックの有 無により出力インピーダンスが変化することがわかる。並 列運転時, $i_{\text {out }}$ をフィードバックする代わりに $i_{L a}$ をフィー ドバックする。負荷から見た出力インピーダンス $Z_{\text {outa }}$ と並 列する相手側インバータから見た出力インピーダンス $Z_{\text {outs }}$ の 2 つが存在する。これらは，大きさが 10 倍，位相が $90^{\circ}$ 異なる。

これら $Z_{\text {outa }}, Z_{\text {outs }}$ 用いて並列運転時の単相等価回路を描 くと図 11 のようになる。インバータ間の循環電流 $i_{\mathrm{cir}}$ は $Z_{\text {outs }}$ に依存し, インバータの出力性能は $Z_{\text {outa }}$ により規定 される。

〈4·2〉並列制御系の構成＼cjkstart図 9(b) に示す循環電流制 御器（破線で囲まれる部分）は， $Z_{\text {outs }}, Z_{\text {outa }}$ の特性に従い

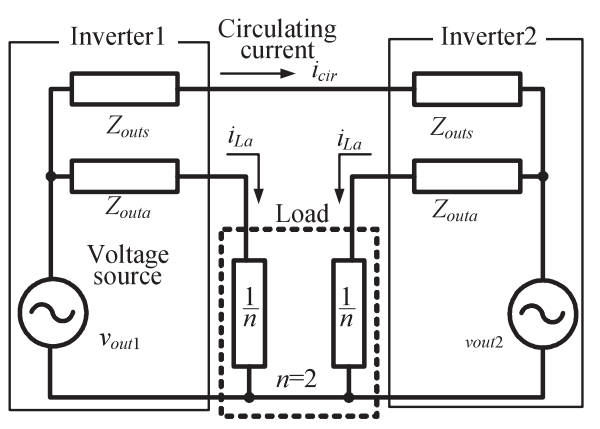

図 11 図 9 の等価回路

Fig. 11. Equivalent circuit of Fig. 9.

構成されている。 $Z_{\text {outs }}$ が抵抗性であるため, インバータの 出力電圧に位相差がある場合, 循環電流は無効分が流れる。 そこで, 循環電流を出力電流と負荷平均電流の差, すなわち $i_{\text {out }}-i_{\mathrm{La}}$ を求め, その無効分 $p_{\mathrm{r}}$ を下記式で計算している。

$$
\begin{aligned}
p_{r}= & \left(v_{\text {outu }}-v_{\text {outv }}\right) i_{\text {cirw }}+\left(v_{\text {outv }}-v_{\text {outw }}\right) i_{\text {ciru }} \\
& +\left(v_{\text {outw }}-v_{\text {outu }}\right) i_{\text {cirv }} \ldots \ldots \ldots \ldots \ldots \ldots \ldots
\end{aligned}
$$

そして, $p_{\mathrm{r}}$ にゲインを乗じて周波数補正量 $\Delta f$ としている。 前節で示した $\mathrm{P}-\mathrm{Q}$ 方式と同様, 並列運転時の出力電圧差を 調整する機構は $Z_{\text {outs }}$ の大きさによれば不要である。単機定 格運転時, 出力電圧の差を各インバータにおいて, $\pm 1.0 \% に$ なるように出力電圧センサのゲイン, オフセットを調整す る。これにより並列運転時の出力電圧の振幅誤差は $2 \%$ (相 電圧 $2.31 \mathrm{~V})$ が最大である。この電圧差に対する循環電流 は, $2.31 \mathrm{~V} / 2 \mathrm{x} 0.25 \Omega=4.62 \mathrm{~A}$ となる。この循環電流の值 は定格電流 $288 \mathrm{~A}$ の $1.6 \%$ であり, 実用上問題ない值であ る。以上のことから, 従来の制御法にあるような電圧差の 修正を行う必要がないことがわかった。

〈4·3〉 実験結果 単機容量 $100 \mathrm{kVA}$ の三相インバー 夕を 3 台並列運転（1 台圥長）し，200 kVA のシステムを 構成した場合の実験結果を示す。

図 12(a) は定格整流器負荷 $200 \mathrm{kVA}$ 時の出力電圧, 出力 電流波形である。電圧波形ひずみ率は $1.4 \% て ゙ あ り ，$ 単機運 転時の特性とほぼ同等の值が得られた。前述の通り, 負荷 に対する出力インピーダンス $Z_{\text {outa }}$ は単機の $Z_{\text {out }}$ と同一の 值が得られるためである。

図 12(b) はNo.1，No.2 インバータを並列した状態で, No.3インバータをこれらに並列接続したときの波形であ る。インバータNo.3の投入直後にそれぞれのインバータ は負荷を $1 / 3$ 分担する。各インバー夕に出力電圧調整機能 を備えていないが, 投入直後, 過大な循環電流はながれて いない。また, 定常時では, 循環電流は定格電流の $\pm 3 \%$ 以 下となっている。前述の通り, インバータに対する出力イ ンピーダンス $Z_{\text {outs }}$ は単機の $Z_{\text {out }}$ より 10 倍大きく, 電圧差 があっても循環電流は流れにくいためである。 $Z_{\text {outs }}$ 求めた 計算值よりは大きくなっているが，実使用上問題ない。

図 12(c) は 3 台並列運転中, インバータNo.3 の電流セ ンサを故障させた場合である。インバータ No.3にて過電 


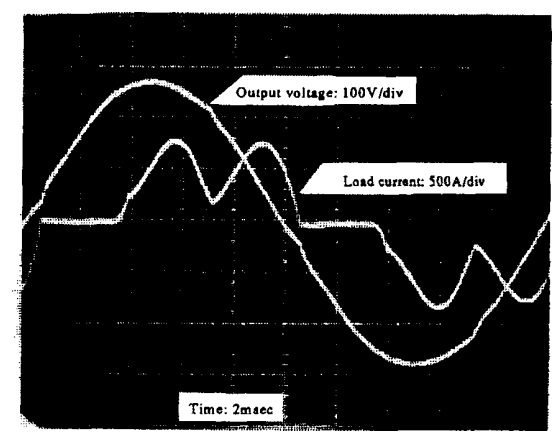

(a) Output voltage and Output current waveform at $200 \mathrm{kVA}$ rectifier load

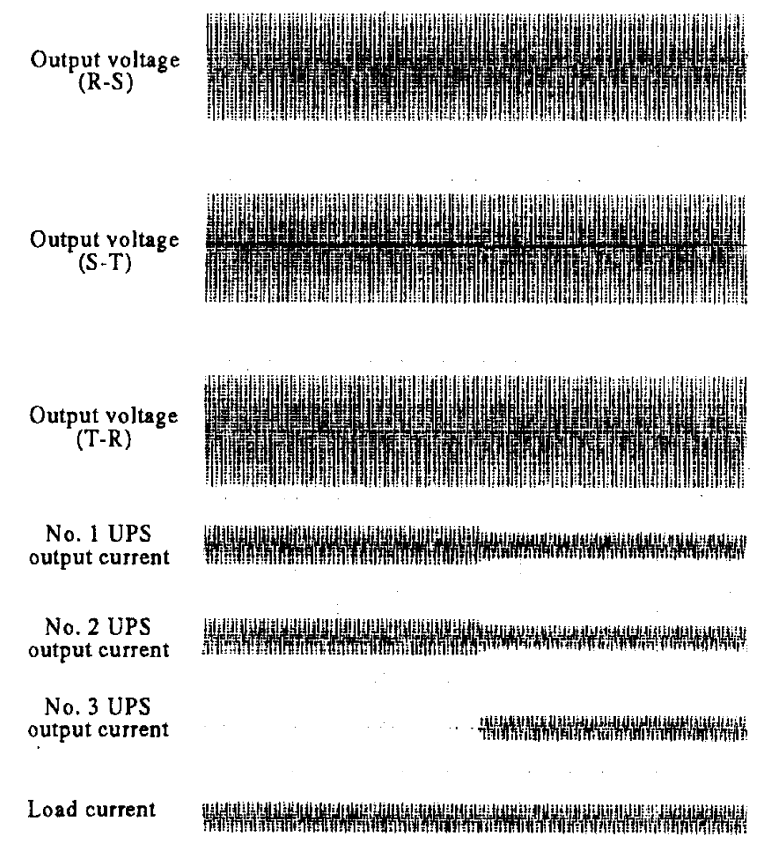

(b) No.3 Inverter 投入

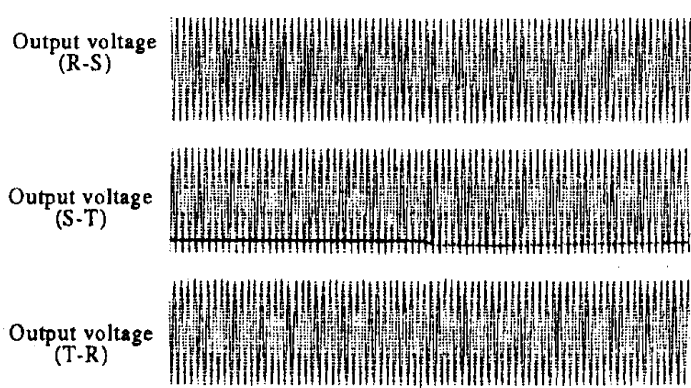

No. 1 UPS
output current

No. 2 UPS
output current

No. 3 UPS

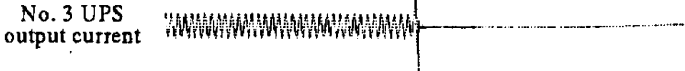

Load current

Fault detect

signal

図 $12100 \mathrm{kVA}$ インバータ 3 台並列運転実験結果（200kVA システム 1 台圥長）

Fig. 12. Experimental results for three $100 \mathrm{kVA}$-inverters connected in parallel (200 kVA system, one unit is redundant).

流が発生している。インバータNo.3のみ過電流を検出し, 運転を停止, 解列している。出力電圧の変動は $5 \%$ 以内と なっている。

以上，構築した並列制御系の有用性が確認できた。

\section{5. おわりに}

本論文ではインバータ単機の出力インピーダンス特性に 着目し, 並列運転の制御系を構成し, 次のことが得られた。

（1）出力インピーダンスは，負荷電流を外乱としモデ ル化した出力電圧制御系のブロック線図において外乱伝達 関数から求めることができた。

（2）並列運転時，インバー夕の電圧差，位相差でイン バー夕間に流れる循環電流の大きさ, 位相は, 出力インピー ダンスに依存すること 3 つの例を上げて示し, シミュレー ションで確認した。

（3）出力インピーダンスはL-Cフィルタのリアクトル 值，制御系の補償器の構成だけでなく，デッドタイムの影
響も受けることがわかった。

（4） PQ 垂下方式と共通電流検出方式について並列制 御系の構成事例を示した。出力インピーダンスを考察した 結果, 両事例ともに抵抗性となることがわかった。従って, $\mathrm{PQ}$ 垂下方式では, 出力電流の無効分を検出し出力周波数 に垂下特性を付加した。共通電流検出方式では, 循環電流 の無効分を検出し, 出力周波数に垂下特性を付加した。

（5）両事例ともに, 出力インピーダンスの大きさから 循環電流を計算すると問題ない值にできることがわかった ので，従来方式にあるような並列運転時の出力電圧を調整 する機能を付加しなかった。実験により，この妥当性を確 認できた。

以上, インバータ並列システムを設計する上で出力イン ピーダンス特性を把握することで適切な並列制御系が構築 でき, 設計の効率向上, 制御系の信頼性向上, アルゴリズ ムの簡素化が達成できる。

最後に本研究を遂行するに当たり, 多大なるご協力を頂 
きましたサンケン電気河内祥一氏，井山治氏に感謝の意を 表します。

(平成 18 年 11 月 13 日受付, 平成 19 年 10 月 14 日再受付)

\section{文献}

(1) K. Matsuzaki: "Technology for Highly Dependable Large Capacity UPS System", Trans. IEE of Japan, Vol.114-D, No.3, p.260 (1994) (in Japanese) 松崎 薰:「大規模無停電電源システムの高信頼化技術」, 電学論, 114-D, 3 p.260 (1994)

(2) Y. Hayashi, T. Ise, K. Tsuji, K. Shimizu, and F. Inui: "A Power Control Scheme between Quality Control Centers in FRIENDS", Trans. IEE of Japan, Vol.123-B, No.12, pp.1445-1453 (2003-12) (in Japanese) 林 祐介・伊瀬敏史 · 辻毅一郎 - 清水慶一・乾 史樹：「FRIENDS における複数の電力改質センターを考慮した連系運転制御」, 電学論, 123-B, 12, pp.1445-1453 (2003-12)

(3) T. Kawabata and S. Higashino: "Parallel Operation of Voltage Source Inverters", IEEE Trans. on Industry Applications, Vol.24, No.2, pp.281-287 (1988)

(4) S. Fujii, M. Shimizu, and M. Nakamura: "Development of Sine Wave Inverter Generating System", HONDA R\&D Technical Review, Vol.8, pp.7076 (1996)

藤井 茂・清水元寿・中村政史：「正弦波インバータ発電システムの 構築」, HONDA R\&D Technical Review, Vol.8, pp.70-76 (1996)

(5) A. Takeuchi and S. Kondo: "Experimental Results of Phase Synchronizing Control in 10 PWM Inverters Parallel Operation", Conf. Rec. of JIASC, pp.249-252 (2001) (in Japanese) 竹内 篤・近藤正示：「10 台の PWM インバータによる位相同期制 御の検証結果」, 平 13 電学産業応用部大, pp.249-252 (2001)

(6) E.K. Sato and A. Kawamura: "Design of an Autonomous Control for Parallel-Connected Uninterruptible Power Supplies", Trans. IEE of Japan, Vol.126-D, No.4, pp.444-452 (2006)

(7) Y. Ito and S. Kawauchi: "Microprocessor-Based Robust Digital Control for UPS with Three-Phase PWM Inverter", IEEE Trans. on PE, Vol.10, No.2, pp.1-9 (1995)

付 録

Case1 の外乱伝達関数

$$
G_{d}(s)=-\frac{\omega_{c}^{2} L s}{s^{2}+\omega_{c}^{2}}, \quad \omega_{c}=\frac{1}{\sqrt{L C}}
$$

Case 2 の外乱伝達関数

$$
G_{d}(s)=-\frac{\omega_{c}^{2}\left(L s+r_{d}\right)}{s^{2}+\frac{r_{d}}{L} s+\omega_{c}^{2}}, \quad \omega_{c}=\frac{1}{\sqrt{L C}}
$$

Case 3 の外乱伝達関数

$$
G_{d}(s)=-\frac{\left(\frac{L}{K_{i} E_{d}} s^{2}+\frac{r_{d}+E_{d}}{K_{i} E_{d}} s\right) \frac{K_{i} E_{d}}{L C}}{s^{3}+\left(\frac{r_{d} E_{d}}{L}\right) s^{2}+\left(\frac{1+K_{p} E_{d}}{L C}\right) s+\frac{K_{i} E_{d}}{L C}}
$$

伊 東 洋 一 (正員) 1966 年 2 月 1 日生。 1990 年 3 月長岡技

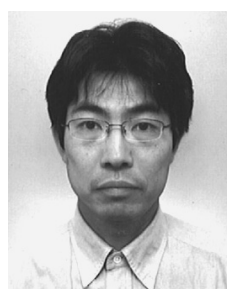
術科学大学大学院修士課程修了。同年 4 月サンケ ン電気（株）入社， 2002 年 3 月まで勤務。同年 3 月よりマイウェイ技研（株）入社，現在に至る。 工学博士 (東京工業大学)。無停電電源装置, 分 散型電源システムにおける電力変換器のデジタル 制御法に関する研究開発，製品開発に従事。

赤 木 泰 文 (正員) 1951 年 8 月 19 日生。1979 年 3 月東京

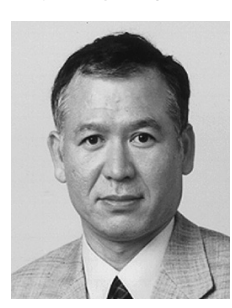
工業大学大学院電気工学専攻博士課程修了。工学 博士。長岡技術科学大学助手 ·助教授, 岡山大学 教授を経て，2000 年 1 月東京工業大学教授。パ ワーエレクトロニクスの研究に従事。電気学会論 文賞を 4 回, IEEE IAS/PELS Transactions Prize Paper Award を 4 回, IEEE IAS Committee Prize Paper Award を 9 回受賞。1996 年 IEEE Fellow。1998 年 IEEE IAS/PELS Distinguished Lecturer。2001 年 IEEE William E. Newell Power Electronics Award。2004 年 IEEE IAS Outstanding Achievement Award。2006 年文部科学大臣表彰・科学技術賞（研究部門）受賞。

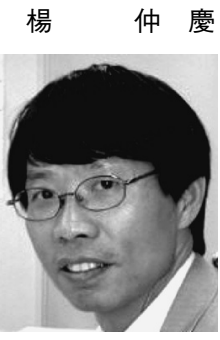

工学博士。
（正員） 1962 年 6 月 1 日生。 1990 年 9 月東京 工業大学大学院電気工学専攻博士課程修了。同年 10 月，東洋電機製造（株）に入社，1993 年 7 月 退社，同年 8 月マイウェイ技研（株）設立（代表 取締役社長)。パワーエレクトロニクスにおける 技術サービス業に従事。主に分散型電源や電気自 動車用のモーター・ドライバの開発，製品化を行 う。1999 年 11 月から西安交通大学, 特聘教授。 